\section{SOI: $1.1 /$ TAS DOI: $10.15863 /$ TAS International Scientific Journal Theoretical \& Applied Science}

\author{
p-ISSN: 2308-4944 (print) e-ISSN: 2409-0085 (online) \\ Year: 2017 Issue: 03 Volume: 47
}

Published: $30.03 .2017 \quad$ http://T-Science.org

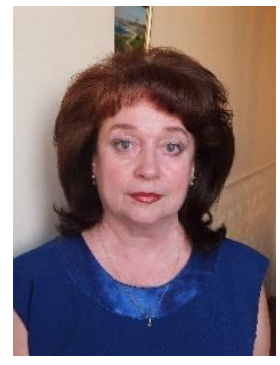

Elena Ananyeva Doctor of Philosophy, Associate Professor. Department of General Psychology SEGI KFU behalf V. Vernadsky, Russian Federation filosvit@mail.ru

SECTION 21. Pedagogy. Psychology. Innovations in the field of education.

\title{
PSYCHOLOGY OF RELIGION IN THE SYSTEM OF SCIENTIFIC KNOWLEDGE: DETERMINING THE SUBJECT OF RESEARCH
}

Abstract: The article examines the problems of researching the psychology of religion as an independent discipline within the framework of socio-psychological knowledge. Theoretical questions are raised at the junction of social psychology and religious studies, which lead to the development of a new methodology, a new conceptual research apparatus, which is reflected in the definition of the subject of the psychology of religion.

Key words: The psychology of religion, the subject of the psychology of religion, religiosity, religious worldview, religious phenomena, social psychology, the philosophy of religion.

Language: Russian

Citation: Ananyeva E (2017) PSYCHOLOGY OF RELIGION IN THE SYSTEM OF SCIENTIFIC KNOWLEDGE: DETERMINING THE SUBJECT OF RESEARCH. ISJ Theoretical \& Applied Science, 03 (47): 109-113.

Soi: $\underline{\text { http://s-o-i.org/1.1/TAS-03-47-20 Doi: crossef https://dx.doi.org/10.15863/TAS.2017.03.47.20 }}$

\section{ПСИХОЛОГИЯ РЕЛИГИИ В СИСТЕМЕ НАУЧНОГО ЗНАНИЯ: ОПРЕДЕЛЕНИЕ ПРЕДМЕТА ИССЛЕДОВАНИЯ}

Аннотация: В статье рассматриваются проблемы исследования психологии религии как самостоятельной дисииплины в рамках сочиально-психологического знания. Поднимаются теоретические вопросы, находящиеся на стыке сочиальной психологии и религиоведения, которые ведут к выработке новой методологии, нового понятийного аппарата исследования, что отражается в определении предмета психологи религии.

Ключевые слова: Психология религии, предмет психологии религии, религиозность, религиозное мировоззрение, религиозные явления, соцчильная психология, философия религии.

\section{Введение}

Вопрос установления места психологии религии в системе научного знания тесно связан с определением предмета данной междисциплинарной дисциплины и заключается в том, следует ли относить психологию религии к психологии или к философии религии, либо к религиоведению. Если психология религии - это часть психологии, то какая из областей последней - индивидуальная или социальная - должна быть преимущественно отражена в исследованиях. В последнее время появилась тенденция, согласно которой психология религии - это самостоятельная наука, с чем во многом можно согласиться. Однако сложность определения психологи религии в таком понимании заключается в том, что методология данной дисциплины зависит от философии и богословского мировоззрения, которые и устанавливают метод определения эмпирических показателей религиозного феномена [7].

\section{Методология}

Большое влияние на развитие психологии религии оказали европейские теологические, философские и психологические традиции. Поэтому проблема предмета изучения психологии религии достаточно полно рассмотрена в отечественной и зарубежной философской, религиоведческой и социальнопсихологической литературе, в том числе в работах, посвященных вопросам психологических проблем религии [5].

Среди них - классический британский эмпиризм на рубеже XVIII-XIX вв., классическая немецкая философия, прежде всего философско- 
трансцендентальная проблематика опыта. Позже на психологию религии оказывали влияние в той или иной мере практически все движения и течения в европейской философии, в которых проблема религиозного опыта занимала заметное место. Необходимо отметить также и влияние на развитие психологии религии философского знания XX века, такого как философская феноменология и аналитическая философия, которые настолько интегрированы в исследование религиозного опыта, что без них исследование уже невозможно представить, по общему мнению, сложившемуся в классическом религиоведении [5].

При всем этом в случае рассмотрения психологии религии как отдельной дисциплины в рамках психологического знания нерешенными будут являться вопросы, связанные с проблемами методологической базы большинства исследований феномена индивидуальной религиозности. Возникает ряд сложных теоретических вопросов, находящихся на стыке социальной психологии и религиоведения, которые ведут к необходимости выработки новой методологии, нового понятийного аппарата исследования, что выражается в поиске и определении непосредственного предмета исследования, присущего именно психологии религии как оригинальной научной дисциплины.

Целью статьи является анализ вопросов по определению предмета психологии религии, поскольку признание психологии религии самостоятельной дисциплиной обнаруживает, что методика ее исследований зависит от социальнопсихологической методологической базы, от обстоятельств социологического и исторического порядка, и в том числе - от особенностей человеческой психики.

Вопрос определения предмета психологии религии усложняется еще тем, что до появления научной психологии (формально дату ее возникновения связывают с основанием В. Вундтом в 1879 г. первой экспериментальной психологической лаборатории в Лейпциге) проблемы психологии религии оказывались главным образом в лоне философии или теологии [1, c. 46-48].

Однако уже первые попытки систематического изучения психологических проблем религии двигались в направлении эмпиризма и заключали в себе стремление приблизиться к эталонам, выработанным конкретным естественнонаучным знанием. Методологической базой в системе психологической науки для большинства исследователей был позитивизм или стихийный материализм; уже в ранних работах обнаружилась тенденция разграничения задач психологии религии и религиоведения [5].
Однако институционально психология религии практически не была представлена в психологических исследовательских центрах и на факультетах психологии. Более того, специалист по психологии религии чаще находил себе применение в системе религиоведческих, философских или теологических учреждений.

Отнесение психологии религии к социальной психологии либо к общей психологии, либо к религиоведению осложнено трудностью проведения строгой границы между этими областями исследования. На первый взгляд, очевидно, что, будучи явлением социальным, личная религиозность более естественно вписалась бы в контекст социальнопсихологического исследования, что и происходило в начале определения психологии религии. Тем не менее, как показало позднейшее развитие, большинство концепций в психологии религии обязано своим происхождением общей либо индивидуальной психологии: психологии бессознательного, психологии поведения и т. д. При этом, как правило, известные общетеоретические положения о природе индивидуальной психики экстраполировались на проблемы религии и религиозных отношений[6].

Уже на ранних этапах развития психологии религии сформировался подход, предполагающий ограничение объекта исследования исключительно внутренней, или субъективной стороной религии. У. Джемс в своей ставшей классической работе «Многообразие религиозного опыта» определял различие между внутренней и внешней сторонами религии следующим образом: «С первого шага мы встречаем пограничную линию, проходящую через всю область религии. По одной стороне ее находится религия как учреждение, по другой - как личное переживание. <..> Внешний культ, жертвоприношения, воздействие на благосклонность божества, теологические системы, обрядность и церковная организация представляют существенные черты первой ветви. Если бы мы сосредоточили свое внимание на ней, то должны были бы дать религии определение как некоему внешнему действию, имеющему целью привлечение к себе милости богов. Наоборот, в религии личного характера центр, на котором должно сосредоточиться внимание, составляют внутренние переживания человека, его совесть, его одиночество, его беспомощность и несовершенство. <..> Действия, к которым побуждает такого рода религиозность, имеют не обрядовый, а чисто личный характер...». У. Джеймс настойчиво подчеркивал, что именно личная, субъективная область религии составляет объект преимущественного внимания науки [3, c.146]. 
С одной стороны, с этим трудно не согласиться - понимание тех религиозных явлений, которые связаны с внутренним миром человека, возможно прежде всего в рамках психологического исследования. С другой стороны, такое понимание никак нельзя признать универсальным. Представитель, например, бихевиористского направления в психологии занял бы прямо противоположную позицию, заявив, что так называемая внутренняя сторона религиозности не может изучаться вообще, а настоящий предмет исследования может составить только религиозное поведение в его соотношении со средой, в которой оно формируется. Можно согласиться, что такую точку зрения разделили бы последователи И. П. Павлова и В. М. Бехтерева, сторонники теории «инстинктов социального поведения» В. МакДугалла или представители структуралистской школы [4].

Однако, для значительной части исследователей, работавших в области психологии религии, именно подход, сформулированный У. Джемсом, оставался главенствующим на протяжении долгого времени. В поле зрения психологии религии в первую очередь попадали явления субъективного мироощущения человека: переживания, эмоции, восприятия и их переработка, мотивация, намерения, волевые усилия, акты мышления, наконец, память и все еe сознательное и бессознательное содержание [8]. При этом не обязательно речь шла о внутреннем мире индивидов, имеющих религиозную установку, объектом рассмотрения могла стать и психология безрелигиозного индивида, изучаемая под соответствующим углом зрения.

Существует значительный пласт религиозных явлений интерсубъективного характера, к ним относятся, в первую очередь, вероучение и система религиозной социализации (воспитания и обучения). Так, вероучение объективно, поскольку существует вне и независимо от воли и сознания приверженцев той или иной религии, зафиксировано в текстах или устной традиции и сохраняется или развивается усилиями религиозной организации. Однако в то же время оно субъективно, т. е. интериоризировано, известно верующим и воспринято ими как система своих, внутренних ценностей, составляет фундамент их внутренней религиозности [8]. Аналогичным образом система религиозной социализации, включающая все исторические формы трансляции религиозности из поколения в поколение, от первобытных инициаций до духовных академий также объективна - она есть данность общественной жизни, существующая вне и независимо от отдельных людей, в частности, тех, кто оказывается в сфере ее влияния. Кроме того, используя объективированные, социально закрепленные стандарты - методы воспитания и обучения, учебники, эталоны, авторитеты и т. п., она, в конечном итоге, приводит к тому, что вырабатываются стереотипы внутренней религиозности индивидов - каноны религиозного переживания, религиозного мышления, религиозно направленного волевого акта. Их выработка является конечной задачей системы, и потому они выступают как формирующий существенный ее принцип. В религиозной жизни большое значение имеет именно интерсубъективный характер этих составляющих: для верующего, как правило, и очевидно, и важно, что содержания, образующие его внутреннюю религиозность, являются существенным связующим звеном между ним и религиозной организацией, между ним и единоверцами, а это само по себе представляет важный психологический факт [8].

Если в настоящее время попытаться указать фактический предмет психологии религии как части психологической науки, то внутренний мир верующего будет отнесен к нему без колебаний. Однако внешняя сторона религии - религиозные организации, культ и его материальные атрибуты, религиозное поведение, характер жизнедеятельности религиозных индивидов, сообществ, иерархий, лидеров и т. д., - стала объектом внимания исследователей социальной психологии. Психология религии, в свою очередь, находит тесную связь с социальной психологией, поскольку во внешнем пласте религиозных явлений присутствуют аспекты, которые находят существенное и преимущественное объяснение не столько в обстоятельствах социологического или исторического порядка, сколько в особенностях человеческой психики.

Таким образом, при выделении психологии религии в качестве отдельной научной дисциплины очень трудно дать единое определение предмета психологии религии, которое не вызвало бы возражений. Если сформулировать дефиницию, которая максимально точно отражала бы реальную картину исследований в данной области и была по возможности более нейтральной по отношению к уже известным школам и парадигмам, то можно согласиться с определением предмета психологии религии как изучения психологических аспектов и закономерностей религиозных явлений [8].

Однако психология религии может строиться на базе не только естественнонаучного рационализма, но и религиозного мировоззрения. В этом случае говорят о конфессиональной, или конфессионально 
ориентированной психологии религии. Она иногда существует в институциональных рамках некоторой религиозной организации, а иногда развивается вне и независимо от таковой: так, христианскую конфессиональную психологию религии можно подразделить на церковную и внецерковную [2].

Кроме этого, заметное место занимает психология религии в теоретических исследованиях, ведущихся под эгидой католической церкви и протестантских церквей на Западе. Такое воплощение психологии религии связано, главным образом, с внутренними задачами церковной жизни и интерпретацией вероучения. Это связано с широким внедрением психологии и психотерапии в практическую повседневную жизнь католического или протестантского прихода, почву для чего подготовила прежде всего давняя и богатая традиция душепопечительской деятельности христианской церкви. Душепопечение предполагает индивидуальную работу священника с прихожанином. Священник идет к верующему как человек к человеку и ведет разговор, предполагающий внимание к личностным особенностям своего подопечного, включая, в первую очередь, проблемы его душевной и духовной жизни. Польза определенных психологических знаний и психотерапевтических навыков в такого рода деятельности очевидна, и эти знания и навыки активно используются церковью, начиная с 20-30-х г.г. ХХ в [9, с. 123126].

Другая причина проникновения психологии в христианство связана с необходимостью теологической рефлексии над теми антропологическими выводами, к которым приходит современная психология. Особенно глубоко и заинтересованно работает в этом направлении экзегетика. В этой связи прослеживается единство: психология исследует религию, чтобы дополнить свои знания о человеческой психике изучением феноменов религиозности, христианство использует психологию, чтобы внедрять ее в практику повседневной деятельности священников и укреплять позиции теологии [9, с. 123-126].

Интересно то, что внецерковная конфессионально ориентированная психология религии не связана, как правило, со специфически церковными задачами, но предполагает в качестве методологической базы религиозную антропологию. Например, психолог, организационно независимый от церкви, может переосмыслить с позиций вероучения то, что известно ему из психологической теории и практики. Если в церковной психологии обнаруживается стремление пересмотреть те или иные разделы теологии с позиций психологии, привлечь ее для объяснения и интерпретации тех элементов вероучения и культа, которые в силу своей иррациональности плохо воспринимаются современными верующими, то во внецерковной психологии наблюдается тенденция уйти от жесткого рационализма, пересмотреть основные разделы науки с позиций представления о человеке как о homo religiosus [2].

Для психологов большую проблему создает генезис религии и религиозности. Основываясь на эмпирических методах, современная психология только описывает религиозные факты так, как их воспринимает человек, или группа людей и дает их объяснение с помощью различных теоретических положений. Психология религии разрешает признать трансцендентные опыт и убеждения, не присоединяясь к исследованиям реальности или вероятности трансцендентного предмета. Психология религии не занимается вопросами объективного существования Бога, Его благодати - это вопросы философии и богословия, но она исследует как конкретный человек или группа людей понимает существование Всевышнего и Его действия в жизни этих людей [10].

Подобная практика ставит ряд сложных теоретических вопросов, дает импульс к разработке проблем, находящихся на стыке социальной психологии, психологии личности и религиоведения, а также требует исторических и социологических исследований. Все это ведет к выработке нового инструментария, нового понятийного аппарата, который был бы адекватен для всех сфер психологии религии как отдельной дисциплины. Задание не сводится к выработке некоторого сверх-языка, поскольку в данном случае возникает проблема не столько переименования, так как категориальный аппарат - не совокупность обозначений: категории определяют угол зрения, задают подход к исследованию, в итоге моделируют его объект. Описанная работа ведет к становлению такой модели психологического знания, которое одновременно отражала бы запросы и религии, и психологии. В свете этого необходимо обратить внимание на то, что почти все современные вероучения имеют свою значительную традицию анализирования реальности духовной жизни. Следовательно, сопоставление религиозного и психологического отображений действительности неминуемо поставит вопрос о корреляциях науки и религии - в этом и будет заключаться оригинальность и новация предмета психологии религии в его новейшем выражении. 


\begin{tabular}{|c|c|c|c|c|c|c|}
\hline Impact Factor: & $\begin{array}{l}\text { ISRA (India) } \\
\text { ISI (Dubai, UAF } \\
\text { GIF (Australia) } \\
\text { JIF }\end{array}$ & $\begin{array}{l}=1.344 \\
=0.829 \\
=0.564 \\
=1.500\end{array}$ & $\begin{array}{l}\text { SIS (USA) } \\
\text { PИНЦ (Russia) } \\
\text { ESJI (KZ) } \\
\text { SJIF (Morocco) }\end{array}$ & $\begin{array}{l}=0.912 \\
=0.234 \\
=1.042 \\
=2.031\end{array}$ & $\begin{array}{l}\text { ICV (Poland) } \\
\text { PIF (India) } \\
\text { IBI (India) }\end{array}$ & $\begin{array}{l}=6.630 \\
=1.940 \\
=4.260\end{array}$ \\
\hline
\end{tabular}

\section{Bыводы}

Для того, чтобы рассмотреть развитие личной религиозности средствами психологии религии, необходимо прежде всего, определить основания изучения этого развития. Понимание психологии религии как самостоятельной дисциплины в системе социальнопсихологической науки является приоритетным, поскольку в изучении религиозных явлений присутствуют аспекты, которые находят объяснение как в человеческой психике, так и в обстоятельствах социологического и исторического порядка.
Учитывая это, перспективы дальнейших разработок в данном направлении связаны с изучением феномена религии и религиозности методами и средствами не только социальной и индивидуальной психологии и религиоведения. Наиболее плодотворно религия и религиозность могут быть изучены в рамках психологии религии как отдельной научной дисциплины, обладающей оригинальным предметом, системным объектом исследования, сформированным категориальным аппаратом в целом.

\section{References:}

1. Vundt V (2002) Problemy psihologii narodov / V. Vundt. - M.: EHksmo, 2002. - p. 46-48.

2. Grasseri R (1901) Psihologiya religii. - SPb., 1901. - 283 p.

3. Dzhejms U (1993) Mnogoobrazie religioznogo opyta. Per. s angl. / U. Dzhejms. - M.: Nauka, 1993. - p.146.

4. Zen'ko YM (2002) Psihologiya i religiya. / YU.M. Zen'ko. - SPb., 2002 - 383 p.

5. (1996) Klassiki mirovogo religiovedeniya: Antologiya, 1996, V. 2-h t.: Per. s angl., nem., fr. T. 1. - M.: Kanon+, 1996. - 496 p.

6. Krasnikov AN, Gavrilina LM, EHlbyakan ES (2003) Problemy filosofii religii i religiovedeniya: Uchebnoe posobie / A. N. Krasnikov, L. M. Gavrilina, E. S. EHlbyakan. Kaliningrad: Izd-vo KGU, 2003. - 153 p.
7. (1998) Mesto psihologii religii v sisteme nauk / Available:

www.pstbionline.orthodoxy.ru/.../Psihologiya $+\mathrm{r}$ eligii+4+kurs.doc (Accessed: 25.03.2017).

8. (2005) Osnovy religiovedeniya. Retrieved from Available:

https://books.google.ru/books?isbn=527601023 4 (Accessed: 25.03.2017).

9. Popova MA (1973) Kritika psihologicheskoj apologii religii (Sovremennaya amerikanskaya psihologiya religii). / M.A. Popova - M.: Mysl', 1973.- p. 123-126.

10. Ugrinovich DM (1986) Psihologiya religii. / D.M. Ugrinovich - M., Politizdat, 1986. - p. 152-160. 